\title{
Social ideas in poetry of four female Contemporary poet (Parvin Etesami, Forough Farokhzad, Tahereh Safarzadeh and Simin Behbahani)
}

\author{
Mohsen Izadyar ${ }^{1 *}$, Fatemeh Azizmohammadi ${ }^{2}$ \\ 1Department of Persian Literature, Arak Branch, Islamic Azad University, Arak, Iran. \\ 2Department of English Literature, Arak Branch, Islamic Azad University, Arak, Iran \\ *E-mail address: f-azizmohammadi@iau-arak.ac.ir, izadyar.mohsen@yahoo.com
}

\begin{abstract}
This artile with social view point is going to study the social thought of Forough's poem, specially based of female, freedom, tradition and modernity. It focuses on these features of Forough's poem from a different point of view towards social issues. This article studies the social meanings of Forough's poem that are specialized for her. It tries to show the feminism poem which is unique in Iran. After these survey, the article tries to assert that Forough Frokhzad is the most social female poet in Iran; Forough with her courage and boldness used a kind of norm breaking through her poems and speak about social issues. So she could omit some of taboos that belongs to feminine society in Iran.
\end{abstract}

Keywords: Contemporary; social thoughts; feminine; freedom; tradition; morality

\section{INTRODUCTION}

It is safe to say that women's poetry, from the fourth century to the beginning of the constitutional area was strictly passive and limited. However, social and political developments in the era of constitutional democracy in which Woman was seeking modernity and identity reformism, poetry and literature of Iran entered a new era. Serious consideration of writers and poets like Nasim Shomal, Dehkhoda, Adib ol mamalek Farahani, Malek Shoaraye Bahar and the new form of literary criticism, social, political thought in literature and criticism drag acts of repression reflected in the mind and language of women poets. As the presence of women in the cultural field, including the establishment of schools, newspapers and positions such as editors, women poets (mainly from the first group of educated Iranian women) put new dimensions of thought processes and social and historical concerns in their poems. In this period, the works of poets such as Robab Esfahani, Mehrtaj Rakhshan, Nimtaj Salmasi, Fakhr Adel Khalatbary, Shams Kasmaee, Jale. Ghaem Maghami... applied a clear social rebellion of Iranian woman and looking back to their roots:

But after twenty three years of a poet life like Zhale Ghayem,a poet like Parvin Etesami was born on 1285 Shamsi year and she began to write poems since she was seven years old. The late Abodolhosein Zarinkoob while as appreciating Parvin Etesami reminding her as " Parvin a female with male trace in poem and mysticism land ".The reality is while she was a thoughtful poet and aware of the social issues but her using style and language was 
considered as conservative and concealing. In most of her poems she has questioned the women independency and identity with masculine language dominancy and words selections and dictions. For instance she has shown lots of tendencies to Naser Khosro style.

With lots of restrictions for females during the history in Iran's culture, poetry was the only artistic field which a woman can express her thoughts and feelings .In such atmosphere to

Announce your individuality it needs lots of brilliancy and thoughtfulness and it obviously it was not an easy task at all, as Virginia Wolf thought it was the cheapest and the easiest way for women to prove themselves. In such a historical periods while masculine authority demands females to lower their voices as much as no one can recognize them as Ghazali mentioned, then to speak about feelings, experiences ,thoughts and identity needs lots of unusual sacrifice and boldness. About 400 women has proven their identity as a poet in such an anti-feminine culture to send their voices to us over the double pains and suffers. They tolerated Mahasti, Jahan Khatoon and Jamile Esfahani was among such female poets who have become disreputable figures for writing poetry.

Even men poets did not consider female poets so seriously and biographies was written without even mentioning women at all.We have seen so much in our written cultures that female brilliancies have been considered as female wiles and lots of poems have been written to gossip women but the thoughtful and aware women compose poems to maintain in history and we can notice their rebels now and then after centuries.

From Rabeie the first female poets up to Mahasti with her philosophical quatrains, so many years have gone so that a new female poet like Forogh Farokhzad in 1331 Shamsi year, solitarily and rebelliously in a traditional society has risen to reveal the hypocrisy of masculine territory and bravely saw and realized things with her female insights.

\section{SOCIAL IDEAS IN POETRY}

Although the poems have been interpreted as "Rhythmical words that have meaning", it would be meaningful when it is to distinguish between poetry and prose. These definitions and interpretations of the poem is not comprehensive. Obviously from the view points of the Ancients who considered and approved such definitions, other condition is necessary for poetry for example poetry should influence the souls, it means that the available feeling and emotion and imagination should be transferred to others. Thus, considering the emotions of others to create empathy and sympathy and compassion between the poet and the others is a primary condition for poetry. Considering the emotions of the poet does not mean that they should compose poetry according to the needs of society. Mayakovski- as a revolutionary poet- believes that a poet must write the lyrics based on the social order and defined poetry as "the product of the social order". The hidden soul of the poet is undoubtedly influenced by the social and political conditions and circumstances of society upon which the poet lives. And if we accept that the poet is the painful consciousness of the society and extract of his time, and consider poetry as a social phenomenon, the poet's responsibility will be providing his art with regard to this need. Obviously, the requirements of time will be different in each period and each society.

Promotional literature functions as an ideological literature to support the idea that the artist is committed his own ideology and its reflection in the work of art itself. As the birthplace of the Socialist Realism and Naturalism was Russian, it was a reaction against 
Marxism. According to socialism socialist, the task of art is promoting Socialism and the artists in the community are known as the government servant to advertise for a social class. But sometimes the artist is looking for other purposes apart from ideology. It means that the artist apart from any political, religious and social affiliation, deals with art to reform and educate. In this case, it is often pointed out the mistakes and asked the community to improve the situation and correct shortcomings.

\section{PARVIN SOCIAL THOUGHTS}

One significant thing in all of Parvin's poetry is that social justice has priority over political freedom. (Ahmadi, 1388: 44)

Definitely, this issue is related to the period and social backgrounds of the society which Parvin lived in and also to the Parvin style and vision of the social and political problems. Another thing to be considered in Parvin's poetry is her severe skepticism regarding the government and authorities of that time. She always had a critical attitudes towards the government and its institutions. Such strict critical insight was considering the faults and follies of the society based on the corruption and ruination of the government and its institutions rather than criminal and felon's attitudes inside the society.

Parvin tries to guide people through advising and leading them to the right path which is her reaction towards the existing social and political problems of her own society . She totally focused on the culture and beliefs of her society. "Actually the training rule over man's construction and Parvin concern to revise the society moralities based on Islamic religion and culture has made her to recognize the pain of her society with a subtle and reconciling attitude and for its cure she has prescribed advice therapy toward poetry."(Momtahen; Mohammadi, 1390: 124)

Parvin's social thoughts and characteristics can be summarized as below:

1-Fighting with tyranny and injustice

2-Making people aware

3-Equality of men and women rights

4- Necessity of obtaining education for people especially for women

5-Helping others

6-Observing religious and moral rules

7-Considering security and welfare

8-Contentment

9-Omiting social corruptions

10-Justice seeking

11-Ditactic purpose of poetry

12-Not paying attention to cliché love affairs

13-Binary Oppositions against each other

14- Mixture of her feminine vision with political nowadays issues 


\section{MORAL AND RELIGIOUS THOUGHTS}

Parvin's philanthropically thoughts and justice seeking was under the influence of Islam moral and didactic rules and laws which consider human society as a one united body.

\section{Parvin's Humor}

Political autarchy and social turmoil sometimes made the writers and poets to write in humor and allusion for their conservative and security purposes such as Soozani Samarghandi, Obeide Zakani, Sa'adi and Hafez from the past and Iraj Mirza,Parvin Etesami, Forogh Farokhzad and Omran Salahi and etc in contemporary times who showed their rebels against the social political chaos of their times by choosing such writing styles.

Among the wide range of poetry contents in Persian language it can be said that Objection poem is the result of Iranian critical and humorous taste. This kind of content have been used by many Iranian Poets but particularly it is considerable since 1300 Hejri Shamsi year. (Poshtdar, 1385: 7-9). Parvin Etesami has expressed her protest in various styles such as allegory and parable in Persian language. From 1300 Hejri Shamsi ( Ghajar dynasty decadence ) till 1314 Hejri Shamsi ( The zenith of Reza Shah autarchy ) she has been used styles which form the objects language ,birds, inanimate objects and abstract concepts like hope and despair ,youth and oldness ,... shows her obvious and hidden criticism towards ignorance and vanity, ravage of oppressed properties, pious pretending, luxurious tendencies, insecurity, autarchy and colonialism .( Kerachi , 1383: 27)

In the verse that are written in the form of Mosammat, Masnavi, Ode and Qeteh, her satirical debate has clear manifestation. In so far that can consider Parvin as one of the contemporary satirical features that has out distanced her rivals especially in debates. In her collection poems there are more than 120 debates that there are hidden satirical and objection about all of them. Parvin Etesami in acknowledgement of his objection and reproof uttered serious speech in clothing with irony and satire to put much more impression. Her satires are occasionally sharp with barbs of objection and passing. Her sharp satire in form of Qeteh, in dispute including "two droped blood" that one dropped from the hand of merchant and the other from the leg of depicts contradiction between poverty and plenty, and satire of this poem is beholder of social imbalance.

The important note is that Prvin's attention on the issue of woman and her defense on equality of man and woman's right is not any inconsistent with Islamic cultural point of view. What Parvin cares about it is to depict her critical view upon the patriarchal society which attaches no little identity and credibility to woman. She wants woman to be identified and out sided from passive mood in order to take part in social and scientific field. Depending on religious and traditional values, parvin tries to guide human being toward human truth. Tries to depict the society which involves poverty, imbalance, corruption, invidiousness, animosity and social selfishness to show off goodness and badness. Sometimes sets society subject of justification and sometimes seats herself on the tribunal.

\section{LOVE}

If esteem love as sensual accord or consider love as brand of those loves that seen in the poems of classical poets such as Khorasani and Iraqi style we should say that in Parvin's poem love has no place such a meaning, on the other hand parvin's social critical soul 
prevents her to pay attention to personal affair and to make them capital of her poetic troubles and subjects.

It is while that her womanhood and abortive conjugal experience was a fitted field for attention to love affair. Also woman that is well aware of woman's problems and insists on equality with woman and man's right. On the whole in everywhere of Parvin's Divan just one or two times have been settled to love affair but superficially.

\section{Woman in Parvin's poem}

Woman possess high situation in Parvin's poem regardless being involved in excess and dissipation, for example to prefer woman over man she respected woman and attached more credit and great importance to them than whatever was also for them in society. She notices to the issue of woman up to the great rank that even selected title of "woman in history" for her topic research paper, and as her poems in this essay doesn't pay attention to the orient grief and affliction in Iran. She depicts their pathetic situation in addition knows the teaching and training as a narrow escape of such a condition. Up to this rank she has erected up in her poem to the advocacy of woman's right as manner that we can suppose her as the first pioneer of Iranian woman poet in protection to the pressure of society over the women. Up to before parvin in poetry field we had never womanhood deep view upon the world. For Parvin woman has higher up position. Woman in Parvin's poem neither embattle in satanic fancy nor is such those kinds that claimants of modernity advertised them. Woman in Parvin's poem while keeps her identity and culture has also distinction for herself, she is able to work alongside the men in social field, she can learn and can teach. We should consider that Parvin lived in the period that Iranian social condition wasn't receptive to active role of women in society and it is clear that in such a condition women couldn't play active role in political game so we can't anticipate revolutionary and political poem by parvin, withal poetry period for parvin is at the point in time that most of the political and revolutionary poet were in the shell of silence, and the younger get involved in romanticism. Moral and philosophical themes are content and issue of Parvin's poems. Correspondingly we should say that Parvin never criticized political issue directly and explicitly yet, description of her poem is criticism of society which it's political and social problems are numerous.

\section{Tradition and Modernism in the poem of Forough}

Proportionally that Forough was pioneer in heretic womanhood she has been also pioneer in the field of cultural modernism. Notwithstanding countless limitation that social condition of the time of Forough has forgotten, she talks about her womanhood propensities, but in spite of decreasing rate of nervousness's and prejudices in next decays, none of woman poet and Persian literature after Forough couldn't able to seize orb precession from the cultural modernism point of view. In this field statements of doctor Shafiee Kadkani about Forough is remarkable: "Forough is one of the features that title of broad minded hold her truly". Meaning and features of her poems are modern and there is no mask if intellectual traits on her personality. Forough is lucid and true in her personality, the same she feels the same she says. We can see her iconoclasm and modernity in her description well. Forough doesn't tussle with the tradition openly because tradition is a static phenomenon and traditional view is a confident view, but Forough's view yet through his disruptions is a view that everything in it is, disorderly, astray, anxious, anguished, confused, transient, untidy, pasty pale, ill defined, void, fugitive, far off, distraught, order less , impartial, stormy, useless, 
cheap, vague, lost, mysterious, restless, guilty, unsettled, misty, loose, tired, sleepy, defaced, winding. Forough is a broad minded that depicts rapture of the tradition on the basis of its failure. She has stood against tradition in contention.

\section{Effective factors on Forugh's social thought}

Forugh's poetry is above all a reflection of social issues of the day. Certainly social and environmental conditions at her time has great influence on her poetry. Her family circumstances and her upbringing has been effective in shaping Forugh's character and social thought. Disregarding her poetic art, and the violence of her father had a profound influence on her emotions and thoughts. The unsuccessful marriage of Forugh and Parviz Shapoor and subsequently her familiarity with Ebrahim Golestan, are factors that have contributed to the formation of his social thought.

\section{Tahereh Safar Zadeh}

Tahereh Safar zadeh as a result of the studies in the literature have introduced a new style of poetry named "resonance" which was very controversial in the beginning because the resistance poetry and political satire was not popular for the government. Finally, for writing religious tolerance poetry, she was expelled and forced to stay home. During time of her loneliness and observing the treacheries of social and political issues, she was more aware of God's support. She developed severe evolution in the way that spend all her time reading and interpretation of the Qur'anic Studies. One of the characteristics of her poem is her attention to religious features especially Shiite. According to her, a poet like Allama Iqbal Lahori is considered as a "reformers" who believes that a poet is a "social reformer". Therefore, the teachings of religious ethics is evident in many of her poems.

\section{Religious faith}

Tahere SafarZadeh is one of the participants started Nimaee religious poetry and one of the founders of the Organization of Islamic Art. Her faith in religion is not confined to the realm of poetry and poetic, she extends it to the social and political activities so that at the beginning of the glorious Islamic movement with the help of prominent and Muslim writers committed to the establishment of the "Cultural Center of the Islamic movement". During her responsibility in pre-revolutionary period nearly 300 students were trained in various disciplines who became the most prominent figures in the arts and culture after the revolution.

After the death of Forugh, the world was facing a serious lack of femininity in contemporary poetry and lack of other Forughs was clearly evident in the poem until the day in which Tahereh Safar Zadeh as a poet who was not raised at that time, after a trip to America began to change the poetry in a way that she partially filled the vacancies of Forugh. Although she makes some excursions in the structure of modern poetry, the fact is that Forugh's modernism is much earlier and stronger than hers.

\section{Woman in poems of Tahereh Safar Zadeh}

A feature of her poetry before the Islamic Revolution was her approach to women who are not traditional anymore rather influence in the country's ongoing political and social issues. She added new capacities for the future poets. 


\section{Simin Behbahani}

Social ideas expressed in the first era of poems of Simin Behbehani in addition to the traditional atmosphere of the poems, are not widespread and do not have much fun, While in the second period of her poetry, the audience goes along with her, and the incident with the emotions. More importantly, the first period of her poetry was allocated to the sole aspect of time and space. In her later poems, this property has been varied by extended temporal and spatial dimensions. One of the secrets of lasting Simin's poems in the second period is her speech with a fresh and modern atmosphere.

Second period of Simin's poems coincides with the Islamic Revolution and the subsequent war. Two major streams in the contemporary Iranian history that have a special place in poetry of Simin. Simin as an Iranian cannot ignore the events of the Revolution and the war. On this occasion, these events became one of the most serious and the most important social issues raised in the Simin's poetry. Behbehani poetry as an expression of social ideas can generally be divided into two periods: Period in which social and political ideas are existed in her poetry but displays simple, ephemeral and superficial things. Most of Simin's poems which have political and social issues during the Islamic Revolution has had this feature. But after the revolution by taking away from the lyric tradition and connect with the audience of her time in the modern world, social and political themes in her poetry that outlined the penetration of depth in the lyric idea. In addition, although the elegance and femininity in Behbehani's poetry reach superior but they are not feministic. Her point of view to women is like a physician who knows the pain and the reason of pain. She deals with the problems of women and does not like to complicate the relationship between women and men.

\section{CONCLUSION}

Forough Farokhzad is the most modernist poet with social issues. She can exalt feminist poem in Iran. Forough is loud Iranian women's voice which have historically been associated with deprivation and discrimination are faced by many. We must say that is the motto of the Iranian phallocentric in all spheres of social, artistic, political, and cultural and shine like can be found below. Forough brought the Persian poems close to modernity and modernism, and thus the most poetic Iranian woman that can be introduced to the world. Forough with her courage and boldness used a kind of norm breaking through her poems and speak about social issues. So she could omit some of taboos that belongs to feminine society in Iran.

\section{References}

[1] Barahi,Reza.Gold Copper.Tehran:Nasher Mo'alef,1371.

[2] Farokhzad,Forough.Full courtpoetry of Forough.Rastin.12 ${ }^{\text {th }}$ of september2011.

[3] Farokhzad,Pooran.Efficient women's website(from yesterday to today).Tehran:Nashreh Ghatreh,1381.

[4] Karimi Hakak,Ahmad.Ushered in the modern Persian poetry.Trans,Masoud Jafari.Tehran:Morvarid,1384. 
[5] Rahimi,Zahra.Man of the Millennium:A comparative study of male and female behavior in Forough's and Safarzadeh's poem.Isfahan:payam Alavi,1388.

[6] Salim,Gholamreza.Socialogy or social literature in Persain literature.Tehran:Toos,1377.

[7] Usefian,MohammadJavad.Social sciences in literature,social issues in the poetry of Fersowsi and Bahar.1377,Journal of social sciences,No.10.

[8] Vahida,Fereidoon.Step in the field of sociology of literature,Iranian sociology Association letter. Article's Collection, 1376. 